\title{
NUGGET TEMPE DENGAN SUBSTITUSI IKAN MUJAIR SEBAGAI ALTERNATIF MAKANAN SUMBER PROTEIN, SERAT, DAN RENDAH LEMAK
}

\author{
Putri Karunia Permatasari, Arintina Rahayuni ${ }^{*}$
}

Program Studi Ilmu Gizi Fakultas Kedokteran Universitas Diponegoro

Jl.Dr.Sutomo No.14, Semarang, Telp (024) 8453708, Email : gizifk@undip.ac.id

\begin{abstract}
Background: One of the nutritional problems in Indonesia are overweight or obesity. Obesity is often affected by the imbalance of food intake and lack of physical activity in children and adults. Imbalance characterized by a high intake of fat intake and the lack of a source of protein and fiber intake. One food source of protein, fiber, and low in fat is soybean. Thus need to do research on tempeh nuggets substituted mujair fish.

Objective: Analyze variation of mujair fish as substitution of tempeh nuggets for protein, fiber, fat content, the acceptance rate, and calculate the amino acid composition of tempeh nuggets substituted mujair fish.

Methods: A randomized experimental design of one factor is tempeh nuggets substituted by mujair fish $10 \%, 10 \%$, $20 \%, 30 \%, 40 \%$, and 50\%). The analysis are protein, fiber, and fat content. Acceptability test are conducted with hedonic test by 20 semi-trained panelists. Statistical analysis of the protein, fiber, and fat content using One Way ANOVA test Cl 95\% for normal distribution of data and Kruskal-wallis test for not normally distributed data. Analysis for the acceptability rate using Friedman test CI 95\% followed by Wilcoxon test.

Results: Variations the mujair fish substitution did not affect the levels of protein, fiber, and fat content in tempeh nuggets. The test results acceptability of aroma, texture and flavor are affected by variations in mujair fish substitution, but does not affect the color of tempeh nuggets. The best treatment was obtained in tempeh nuggets with $20 \%$ substitution of mujair fish has protein content of $14.76 \mathrm{~g}$; fiber content of $216 \mathrm{mg}$; fat content of $16.74 \mathrm{~g}$; essential amino acids methionine $249 \mathrm{mg}$ and cystine $159 \mathrm{mg}$.

Conclusion: Tempeh nuggets with $20 \%$ substitution of mujair fish as the best and preferred panelist, accounted $14,8 \%$ for children aged 6-12 years and 12,3\% for adults aged >15 years based on the RDA of protein, and 0,57\% for children; 0,43\% for adult women, and 0,28\% for adult males based on the needs of daily fiber.
\end{abstract}

Keywords: nuggets; tempeh; mujair fish; protein; fiber; fat

\begin{abstract}
ABSTRAK
Latar Belakang: Salah satu masalah gizi yang terjadi di Indonesia adalah kejadian gizi lebih atau obesitas. Obesitas sering dipengaruhi oleh ketidakseimbangan asupan makanan dan kurangnya aktifitas fisik pada anak maupun dewasa. Ketidakseimbangan asupan makanan ditandai dengan tingginya asupan lemak dan kurangnya asupan sumber protein dan serat. Salah satu bahan pangan sumber protein, serat, dan rendah lemak adalah tempe. Dengan demikian perlu dilakukan penelitian tentang nugget tempe dengan substitusi ikan mujair.

Tujuan: Menganalisis variasi substitusi ikan mujair pada nugget tempe terhadap kadar protein, kadar serat, kadar lemak, tingkat penerimaan, dan menghitung komposisi asam amino esensial nugget tempe dengan substitusi ikan mujair.

Metode: Merupakan penelitian eksperimental rancangan acak lengkap satu faktor yaitu nugget tempe dengan substitusi ikan mujair (0\%, 10\%, 20\%, 30\%, 40\%, dan 50\%). Analisis yang dilakukan adalah analisis kadar protein, kadar serat, dan kadar lemak. Pengujian tingkat penerimaan dilakukan dengan uji hedonik pada 20 orang panelis agak terlatih. Analisis statistik kadar protein, kadar serat, dan kadar lemak menggunakan uji One Way ANOVA Cl 95\% untuk data berdistribusi normal dan uji Kruskal-wallis untuk data berdistribusi tidak normal. Analisis untuk tingkat penerimaan menggunakan uji Friedman CI 95\% dilanjutkan dengan uji Wilcoxon.

Hasil: Variasi substitusi ikan mujair tidak mempengaruhi kadar protein, kadar serat, dan kadar lemak pada nugget tempe. Hasil uji tingkat penerimaan aroma, tekstur, dan rasa dipengaruhi oleh variasi substitusi ikan mujair, namun tidak mempengaruhi warna dari nugget tempe. Perlakuan terbaik diperoleh pada nugget tempe dengan substitusi ikan mujair 20\% dengan kadar protein 14,76g; kadar serat 216mg; kadar lemak 16,74g; asam amino esensial metionin $249 \mathrm{mg}$ dan sistin 159mg.

Simpulan: Nugget tempe dengan substitusi ikan mujair $20 \%$ sebagai hasil terbaik dan disukai panelis, menyumbang 14,8\% bagi anak usia 6-12 tahun dan 12,3\% bagi dewasa usia >15 tahun berdasarkan AKG protein, serta 0,57\% untuk anak-anak; 0,43\% untuk wanita dewasa; dan 0,28\% untuk pria dewasa berdasarkan kebutuhan serat per hari.
\end{abstract}

Kata Kunci: nugget; tempe; ikan mujair; protein; serat; lemak

\footnotetext{
${ }^{*}$ Penulis Penanggungjawab
} 


\section{PENDAHULUAN}

Status gizi memiliki pengaruh sangat besar dalam mewujudkan sumber daya manusia yang berkualitas di masa yang akan datang. ${ }^{1}$ Namun, saat ini masih terdapat masalah gizi yang terjadi di Indonesia. Salah satu masalah gizi yang terjadi adalah gizi lebih atau obesitas pada anak maupun dewasa. Berdasarkan data Riskesdas Jawa Tengah 2007, diketahui prevalensi gizi lebih pada anak laki-laki sebesar 6,6\%; pada anak perempuan $4,6 \%$ serta $10,4 \%$ prevalensi gizi lebih dan $10,1 \%$ prevalensi obesitas pada dewasa. ${ }^{2}$ Kejadian gizi lebih atau obesitas sering dipengaruhi oleh ketidakseimbangan asupan makanan yang ditandai dengan tingginya asupan lemak dan kurangnya asupan sumber protein maupun serat, serta kurangnya aktifitas fisik pada anak maupun dewasa.

Salah satu jenis bahan makanan yang sering dikonsumsi oleh masyarakat sebagai sumber protein hewani adalah daging ayam. Hal tersebut ditandai dengan meningkatnya produksi komoditi daging ayam pada tahun 2008 sebesar $24,26 \%{ }^{3}$ Kandungan zat gizi yang terdapat pada $100 \mathrm{~g}$ ayam adalah air 55,9g; energi $298 \mathrm{kkal}$; karbohidrat 0g; protein 18,2g; dan lemak 25g. ${ }^{4}$ Ayam biasanya diolah dalam berbagai bentuk makanan, salah satu bentuk olahan ayam yang disukai adalah nugget.

Nugget merupakan produk olahan dalam bentuk beku yang bersifat siap untuk dimasak. Setelah penggorengan di dalam minyak panas selama 5 menit, maka nugget sudah bisa disajikan untuk dimakan. Nugget biasanya diolah dari bahan daging giling (daging ikan atau daging ayam) yang diberi bumbu, dipipihkan dan dicetak dengan berbagai bentuk. Potongan ini dilapisi tepung berbumbu, kemudian dikemas dan dibekukan.

Kandungan lemak yang tinggi pada ayam dapat diganti dengan sumber bahan pangan lokal yaitu tempe yang memiliki kandungan protein tinggi namun lemaknya rendah. Tempe merupakan makanan sumber protein, serat pangan, kalsium, vitamin B dan zat besi. Tempe dibuat dengan cara fermentasi atau peragian menggunakan kapang Rhyzophus sp pada substrat kedelai, sehingga membentuk massa yang padat dan kompak. Kandungan gizi dalam $100 \mathrm{~g}$ tempe kedelai adalah air 55,3g; energi $201 \mathrm{kkal}$; protein 20,8g; lemak $8,8 \mathrm{~g}$; karbohidrat $13,5 \mathrm{~g}$; dan serat $1,4 \mathrm{~g} .{ }^{4}$

Meskipun sebagai sumber gizi yang baik tetapi ada permasalahan dalam pemanfaatan tempe yaitu tempe termasuk bahan pangan yang mudah rusak, hanya tahan disimpan 1-2 hari di suhu ruang, sehingga tanpa suatu cara pengolahan atau pengawetan, maka penggunaanya akan menjadi terbatas. Cara terbaik untuk mengoptimalkan manfaat tempe adalah dengan mengkonsumsinya setiap hari dalam jumlah yang cukup. ${ }^{6}$

Tempe memiliki kandungan protein tinggi dan serat pangan serta daya cerna baik saat dikonsumsi karena komponen zat gizi diubah menjadi senyawa sederhana yang lebih mudah diserap tubuh oleh mikroorganisme pada saat proses fermentasi. ${ }^{7}$ Namun, tempe memiliki asam amino pembatas yaitu metionin $173 \mathrm{mg} / 100 \mathrm{~g}$ dan sistin $153 \mathrm{mg} / 100 \mathrm{~g}$. Substitusi ikan mujair dilakukan untuk meningkatkan kandungan asam amino pembatas pada pengolahan tempe menjadi nugget. Ikan mujair memiliki kandungan metionin $553 \mathrm{mg} / 100 \mathrm{~g}$ dan sistin $187 \mathrm{mg} / 100 \mathrm{~g}$ serta warna daging yang putih sehingga dapat memperbaiki warna pada nugget tempe. ${ }^{8}$ Kandungan gizi pada 100g ikan mujair adalah air 79,7g; energi $89 \mathrm{kkal}$; protein $18,7 \mathrm{~g}$; lemak 1g; dan karbohidrat $0 \mathrm{~g}$.

Kandungan protein pada tempe dan ikan mujair diharapkan dapat mencukupi kebutuhan asupan protein, sedangkan kandungan serat dalam tempe diharapkan dapat menjadi salah satu alternatif untuk mengurangi masalah gizi lebih atau obesitas pada anak dan dewasa. Oleh sebab itu, untuk memperbaiki umur simpan dan selera konsumsi akan dilakukan pengolahan terhadap tempe dan daging ikan mujair menjadi nugget.

Pada penelitian ini, variabel yang akan diteliti adalah kandungan protein, serat, lemak, dan tingkat penerimaan nugget tempe dengan substitusi ikan mujair. Hal tersebut diharapkan agar nugget tempe dengan substitusi ikan mujair dapat menjadi alternatif makanan sumber protein dan serat, namun rendah lemak untuk mengatasi masalah gizi lebih atau obesitas pada anak dan dewasa.

\section{METODE}

Penelitian yang dilakukan merupakan penelitian dalam bidang food production. Penelitian dilakukan di Laboratorium Ilmu Teknologi Pangan Politeknik Kesehatan Semarang dan Laboratorium Ilmu Pangan Universitas Katolik Soegijapranata Semarang pada bulan Juli hingga Agustus 2012.

Penelitian ini merupakan penelitian eksperimental dengan rancangan acak lengkap satu faktor yaitu nugget tempe dengan substitusi ikan mujair dengan 6 taraf perlakuan berdasarkan persentase substitusi ikan mujair yaitu $\mathrm{N}_{1}=0 \% ; \mathrm{N}_{2}$ $=10 \% ; \mathrm{N}_{3}=20 \% ; \mathrm{N}_{4}=30 \% ; \mathrm{N}_{5}=40 \% ;$ dan $\mathrm{N}_{6}=$ $50 \%$ serta tiap perlakuan dilakukan dua kali pengulangan. 
Komposisi bahan yang digunakan dalam penelitian ini adalah tempe murni malang yang diperoleh di Giant Supermarket dan Swalayan ADA, ikan mujair diperoleh di Pasar Bulu Semarang, roti tawar putih, susu cair low fat, tepung panir, telur ayam, bawang putih, lada, gula pasir, garam, dan minyak goreng. Tahap awal pembuatan nugget tempe yaitu mengukus tempe pada suhu $65-68^{\circ} \mathrm{C}$ selama 30 menit kemudian dihaluskan dengan blender. Ikan mujair di fillet dan dihaluskan lalu ditimbang sesuai persentase $10 \%$, 20\%, 30\%, 40\%, dan 50\% dari jumlah tempe. Mencampurkan roti tawar yang direndam susu cair dengan tempe dan daging ikan mujair sesuai persentase kemudian menambahkan kuning telur ayam dan bumbu yang telah dihaluskan yaitu bawang putih, lada, gula pasir, dan garam. Adonan dikukus pada suhu $65-70^{\circ} \mathrm{C}$ selama 45 menit, kemudian dipotong dadu, dilapisi dengan putih telur dan tepung panir selanjutnya dibekukan dalam frezzer dengan suhu $3^{0} \mathrm{C}$ selama 15 menit lalu digoreng dengan metode deep frying pada minyak panas bersuhu $170-172^{\circ} \mathrm{C}$ selama 3 menit.

Data yang dikumpulkan dari variabel terikat antara lain kadar protein, kadar serat, kadar lemak, dan tingkat penerimaan. Kadar protein diukur menggunakan metode Mikro-Kjeldahl, kadar serat diukur menggunakan metode ADF(Acid Detergent Fiber), dan kadar lemak menggunakan metode Soxhlet. Penilaian tingkat penerimaan menggunakan uji hedonik terhadap warna, rasa, tekstur, dan aroma nugget tempe yang dilakukan oleh 20 orang panelis agak terlatih yaitu mahasiswa Program Studi Ilmu Gizi Universitas Diponegoro dengan 4 skala penilaian yaitu $1=$ sangat tidak suka, $2=$ tidak suka, $3=$ suka, dan $4=$ sangat suka.

Pengaruh variasi substitusi ikan mujair terhadap kadar protein, kadar serat, dan kadar lemak nugget tempe diuji menggunakan uji statistik ANOVA (Analysis of Varians) One Way untuk data yang berdistribusi normal dan Kruskalwallis untuk data yang berdistribusi tidak normal dengan derajat kepercayaan $95 \%$, sedangkan tingkat penerimaan diuji dengan uji Friedman dengan kepercayaan $95 \%$ dilanjutkan dengan posthoc uji Wilcoxon untuk mengetahui beda nyata antar perlakuan.

\section{HASIL \\ 1. Kadar Protein}

Hasil analisis kadar protein nugget menggunakan metode Mikro-Kjeldahl dapat dilihat pada Lampiran 7 dan secara singkat pada Tabel 1. Kadar protein nugget memiliki nilai rerata 14.29$15.05 \mathrm{~g} / 100 \mathrm{~g}$. Kadar protein tertinggi adalah nugget tempe dengan substitusi ikan mujair $10 \%$, sedangkan kadar protein terendah terdapat pada nugget tempe dengan substitusi ikan mujair $40 \%$. Hasil uji statistik Anova One Way menunjukkan bahwa tidak ada pengaruh kadar protein pada nugget tempe yang disubstitusi ikan mujair.

Tabel 1. Hasil Analisis Kadar Protein Nugget Tempe dengan Substitusi Ikan Mujair

\begin{tabular}{cc}
\hline Perlakuan & Kadar Protein $(\mathrm{g} / 100 \mathrm{~g})$ \\
\hline Substitusi 0\% (kontrol) & $14.90 \pm 0.14$ \\
Substitusi 10\% & $15.05 \pm 0.88$ \\
Substitusi 20\% & $14.76 \pm 0.61$ \\
Substitusi 30\% & $14.90 \pm 0.22$ \\
Substitusi 40\% & $14.29 \pm 0,04$ \\
Substitusi 50\% & $14.89 \pm 0.46$ \\
\hline & $\mathrm{p}=0.712$ \\
\hline
\end{tabular}

\section{Kadar Serat}

Hasil analisis kadar serat nugget menggunakan metode ADF (Acid Detergent Fiber) dapat dilihat pada Lampiran 9 dan secara singkat pada Tabel 2. Kadar serat nugget memiliki nilai rerata $122-216,5 \mathrm{mg} / 100 \mathrm{~g}$. Kadar serat tertinggi adalah nugget tempe kontrol, sedangkan kadar serat terendah terdapat pada nugget tempe dengan substitusi ikan mujair 30\%. Hasil uji statistik Kruskal-Wallis menunjukkan bahwa tidak ada pengaruh kadar serat pada nugget tempe yang disubstitusi ikan mujair.

Tabel 2. Hasil Analisis Kadar Serat Nugget Tempe dengan Substitusi Ikan Mujair

\begin{tabular}{cc}
\hline Perlakuan & Kadar Serat $(\mathrm{mg} / 100 \mathrm{~g})$ \\
\hline Substitusi 0\% (kontrol) & $216,5 \pm 0.12$ \\
Substitusi 10\% & $205 \pm 0.13$
\end{tabular}


Substitusi $20 \%$

Substitusi $30 \%$

Substitusi $40 \%$

Substitusi $50 \%$
$216 \pm 0.11$

$122 \pm 0.07$

$135 \pm 0.02$

$185 \pm 0.07$

$\mathrm{p}=0.899$

\section{Kadar Lemak}

Hasil analisis kadar lemak nugget menggunakan metode Soxhlet dapat dilihat pada Lampiran 11 dan secara singkat pada Tabel 3. Kadar lemak nugget memiliki nilai rerata 15.85 $19.08 \mathrm{~g} / 100 \mathrm{~g}$. Kadar lemak tertinggi terdapat pada nugget tempe dengan substitusi ikan mujair 40\%, sedangkan kadar lemak terendah adalah nugget tempe dengan substitusi ikan mujair 30\%. Hasil uji statistik Anova One Way menunjukkan bahwa tidak ada pengaruh kadar lemak pada nugget tempe yang disubstitusi ikan mujair.

Tabel 3. Hasil Analisis Kadar Lemak Nugget Tempe dengan Substitusi Ikan Mujair

\begin{tabular}{cc}
\hline Perlakuan & Kadar Lemak $(\mathrm{g} / 100 \mathrm{~g})$ \\
\hline Substitusi 0\% (kontrol) & $18.13 \pm 4.69$ \\
Substitusi 10\% & $19.02 \pm 0.23$ \\
Substitusi 20\% & $16.74 \pm 4.43$ \\
Substitusi 30\% & $15.85 \pm 0.90$ \\
Substitusi 40\% & $19.08 \pm 1.19$ \\
Substitusi 50\% & $16.29 \pm 2.46$ \\
\hline & $\mathrm{p}=0.762$ \\
\hline
\end{tabular}

\section{Kadar Asam Amino Esensial}

Hasil perhitungan asam amino metionin dan sistin pada nugget tempe substitusi ikan mujair berdasarkan data sekunder kadar asam amino esensial tempe didapatkan hasil bahwa kadar asam amino metionin dan sistin pada nugget mengalami peningkatan. Hal tersebut ditunjukkan secara singkat pada tabel 4.

Tabel 4. Hasil Perhitungan Asam Amino Metionin dan Sistin Berdasarkan Data Sekunder

\begin{tabular}{|c|c|c|c|c|c|}
\hline \multicolumn{6}{|c|}{ Asam Amino Metionin (mg/100g) } \\
\hline Tempe & \multicolumn{5}{|c|}{ Nugget tempe dengan substitusi ikan mujair } \\
\hline & $10 \%$ & $20 \%$ & $30 \%$ & $40 \%$ & $50 \%$ \\
\hline 173 & 211 & 249 & 287 & 325 & 364 \\
\hline \multicolumn{6}{|c|}{ Asam Amino Sistin (mg/100g) } \\
\hline Tempe & \multicolumn{5}{|c|}{ Nugget tempe dengan substitusi ikan mujair } \\
\hline & $10 \%$ & $20 \%$ & $30 \%$ & $40 \%$ & $50 \%$ \\
\hline 153 & 157 & 159 & 163 & 167 & 171 \\
\hline
\end{tabular}

\section{Tingkat Penerimaan}

Tingkat penerimaan nugget tempe substitusi ikan mujair diperoleh melalui uji hedonik yang meliputi warna, aroma, tekstur, dan rasa. Hasil uji tingkat penerimaan terhadap nugget tempe substitusi ikan mujair dapat dilihat pada Lampiran 12 dan rerata hasil uji tingkat penerimaan secara singkat pada Tabel 5 .

Tabel 5. Hasil Analisis Tingkat Penerimaan Nugget Tempe dengan Substitusi Ikan Mujair

\begin{tabular}{ccccccccc}
\hline \multirow{2}{*}{ Perlakuan } & \multicolumn{2}{c}{ Warna } & \multicolumn{2}{c}{ Aroma } & \multicolumn{2}{c}{ Tekstur } & \multicolumn{2}{c}{ Rasa } \\
\cline { 2 - 9 } & Rerata & Ket & Rerata & Ket & Rerata & Ket & Rerata & Ket \\
\hline Kontrol & $2.95 \pm 0$. & Suk & $2.65 \pm 0.6$ & Suk & $2.55 \pm 0.6$ & Suk & $2.70 \pm 0.7$ & \multirow{2}{*}{ Suka } \\
$\mathbf{0 \%}$ & 60 & a & $7^{\mathrm{b}}$ & a & $0^{\mathrm{d}}$ & a & $3^{\text {def }}$ & \\
Substitusi & $2.95 \pm 0$. & Suk & $2.75 \pm 0.6$ & Suk & $2.60 \pm 0.5$ & Suk & $2.45 \pm 0.6$ & Tidak \\
$\mathbf{1 0 \%}$ & 39 & a & $4^{\mathrm{bc}}$ & a & $0^{\mathrm{d}}$ & a & $0^{\mathrm{f}}$ & suka \\
Substitusi & $2.95 \pm 0$. & Suk & $2.95 \pm 0.3$ & Suk & $2.80 \pm 0.5$ & Suk & $2.80 \pm 0.5$ & Suka \\
\hline
\end{tabular}




\begin{tabular}{ccccccccc}
\hline $\mathbf{2 0 \%}$ & 51 & $\mathrm{a}$ & $9^{\text {bd }}$ & $\mathrm{a}$ & $2^{\text {acd }}$ & $\mathrm{a}$ & $2^{\text {bcdf }}$ & \\
Substitusi & $3.10 \pm 0$. & Suk & $3.15 \pm 0.6$ & Suk & $2.65 \pm 0.6$ & Suk & $3.00 \pm 0.6$ & Suka \\
$\mathbf{3 0 \%}$ & 45 & a & $7^{\mathrm{d}}$ & a & $7^{\text {bcd }}$ & a & $5^{\text {acd }}$ & \\
Substitusi & $2.85 \pm 0$. & Suk & $3.20 \pm 0.6$ & Suk & $3.00 \pm 0.6$ & Suk & $3.25 \pm 0.6$ & Suka \\
$\mathbf{4 0 \%}$ & 67 & a & $2^{\mathrm{d}}$ & a & $5^{\text {ac }}$ & a & $4^{\text {a }}$ & \\
Substitusi & $2.95 \pm 0$. & Suk & $3.20 \pm 0.6$ & Suk & $3.05 \pm 0.6$ & Suk & $3.20 \pm 0.7$ & Suka \\
$\mathbf{5 0 \%}$ & 51 & a & $2^{\text {ad }}$ & a & $0^{\mathrm{a}}$ & a & $7^{\text {ae }}$ & \\
\hline \multicolumn{10}{c}{$\mathrm{p}=0.667$} & $\mathrm{p}=0.006$ & $\mathrm{p}=0.002$ & $\mathrm{p}=0.000$ \\
\hline
\end{tabular}

Keterangan : Huruf yang berbeda pada kolom yang sama menunjukkan perbedaan yang nyata berdasarkan uji lanjut wilcoxon $\alpha=5 \%$

Hasil uji tingkat penerimaan nugget untuk parameter warna menunjukkan bahwa tidak ada pengaruh substitusi ikan mujair terhadap warna nugget dengan nilai $\mathrm{p}=0.667$. Nilai rerata pada analisis tingkat penerimaan dengan parameter warna adalah 2.85-3.10. Keseluruhan variasi persentase substitusi ikan mujair termasuk dalam kategori disukai oleh panelis, namun warna nugget yang memiliki skor tertinggi adalah nugget tempe dengan substitusi ikan mujair $30 \%$.

Tingkat penerimaan panelis terhadap parameter aroma ditunjukkan dengan nilai rerata parameter aroma yaitu 2.65-3.20. Seluruh variasi substitusi ikan mujair termasuk dalam kategori suka. Semakin tinggi persentase substitusi ikan mujair, maka semakin disukai oleh panelis.

Kesukaan panelis terhadap tekstur nugget ditunjukkan melalui uji tingkat penerimaan pada parameter tekstur dengan nilai rerata 2.55-3.05 yang seluruhnya termasuk dalam kategori suka. Tekstur nugget yang memiliki skor tertinggi adalah nugget tempe dengan substitusi ikan mujair $50 \%$.

Hasil tingkat penerimaan nugget pada parameter rasa didapatkan nilai rerata 2.45-3.25. Nilai rerata terendah yaitu nugget tempe dengan substitusi ikan mujair 20\% tidak disukai panelis, sedangkan rasa nugget yang memiliki skor tertinggi adalah nugget tempe dengan substitusi ikan mujair $40 \%$.

Berdasarkan hasil analisa statistik, variasi substitusi ikan mujair mempengaruhi tingkat penerimaan panelis terhadap aroma $(\mathrm{p}=0.006)$, tekstur $(\mathrm{p}=0.002)$, dan rasa $(\mathrm{p}=0.000)$ pada nugget. Uji lanjut dengan menggunakan uji Wilcoxon menunjukkan ada perbedaan yang bermakna pada aroma, tekstur, dan rasa nugget tempe substitusi ikan mujair yang dapat dilihat pada Tabel 5.

\section{PEMBAHASAN}

Nugget merupakan produk olahan dalam bentuk beku yang bersifat siap untuk dimasak. Setelah penggorengan di dalam minyak panas selama 5 menit, maka nugget sudah bisa disajikan untuk dimakan. Nugget biasanya diolah dari bahan daging giling (daging ikan atau daging ayam) yang diberi bumbu, dipipihkan dan dicetak dengan berbagai bentuk. Potongan ini dilapisi tepung berbumbu, kemudian dikemas dan dibekukan. ${ }^{5}$ Pada pembuatan nugget tempe substitusi ikan mujair diperlukan pedoman standar uji kualitas kimia yang meliputi kadar protein dan kadar lemak berdasarkan standar kualitas nugget ayam. ${ }^{9}$ Berikut ini adalah syarat mutu nugget ayam :

Tabel 6. Syarat Mutu Nugget Ayam

\begin{tabular}{lll}
\hline Jenis Uji & & Persyaratan \\
\hline $\begin{array}{l}\text { Keadaan } \\
\text { - Aroma }\end{array}$ & & $\begin{array}{l}\text { Normal, sesuai } \\
\text { label }\end{array}$ \\
& & $\begin{array}{l}\text { Normal, sesuai } \\
\text { label }\end{array}$ \\
- Rasa & & Normal \\
- Tekstur & & Maksimal 60 \\
Air & $\%$ bb (\% berat & \\
basah) & $\%$ bb & Minimal 12 \\
Protein & $\%$ Maksimal 20 \\
Lemak & $\%$ bb & Maksimal 25 \\
Karbohidrat & $\%$ bb & \\
\hline
\end{tabular}




\begin{tabular}{|c|c|c|}
\hline Kalsium & $\mathrm{mg} / 100 \mathrm{~g}$ & Maksimal 30 \\
\hline
\end{tabular}

\section{Kadar Protein}

Kadar protein tertinggi adalah pada substitusi ikan mujair 10\%, hal tersebut dikarenakan persentase tempe yang dominan yaitu $90 \%$. Tempe memiliki kandungan protein $20,8 \mathrm{~g}$ menyumbangkan kadar protein cukup besar pada nugget tempe dengan substitusi ikan mujair $10 \%$ bila dibandingkan ikan mujair yang kandungan proteinnya sebesar $18,7 \mathrm{~g} .{ }^{4}$ Kadar protein terendah pada nugget adalah $14,29 \mathrm{~g} / 100 \mathrm{~g}$. Hal tersebut tidak mempengaruhi mutu nugget tempe substitusi ikan mujair karena berdasarkan syarat mutu nugget ayam untuk kadar protein minimal $12 \%$ bb sehingga protein pada nugget tempe substitusi ikan mujair masih dapat diterima. ${ }^{9}$

Mutu protein juga ditentukan dari perbandingan asam-asam amino yang terkandung dalam bahan pangan. Asam amino yang kurang dalam bahan pangan disebut asam amino pembatas. Tempe merupakan sumber bahan pangan nabati dengan mutu protein rendah karena memiliki asam amino pembatas yaitu metionin dan sistin. ${ }^{10}$ Perhitungan kadar asam amino esensial nugget tempe substitusi ikan mujair pada Tabel 4 diperoleh hasil bahwa kadar metionin tempe meningkat sehingga tidak menjadi asam amino pembatas pada nugget, namun tidak berarti pada sistin. Pada Lampiran 15 ditunjukkan bahwa sistin tetap menjadi asam amino pembatas karena hasil perhitungan asam aminonya paling rendah tetapi kadar asam amino esensialnya meningkat bila dibandingkan dengan kadar asam amino sistin tempe sebelum disubstitusi.

Berdasarkan uji statistik diketahui bahwa tidak ada pengaruh substitusi ikan mujair terhadap kadar protein nugget. Hal tersebut dikarenakan kandungan protein tempe sebesar 20,8g tidak berbeda jauh dengan kandungan protein ikan mujair yaitu $18,7 \mathrm{~g}$ sehingga berkurangnya kandungan protein tempe dapat digantikan dengan adanya substitusi ikan mujair.

Berdasarkan Tabel Angka Kecukupan Gizi diketahui kebutuhan protein bagi anak usia 6-12 tahun sebesar $50 \mathrm{~g}$ dan dewasa usia $>15$ tahun sebesar 60g. Hasil uji kadar protein pada nugget tempe substitusi ikan mujair $20 \%$ menyumbangkan kecukupan protein sebesar $14,8 \%$ bagi anak usia 6 12 tahun dan $12,3 \%$ bagi dewasa usia $>15$ tahun berdasarkan $\mathrm{AKG}$ dan standar kebutuhan lauk nabati yaitu $50 \mathrm{~g}$.

\section{Kadar Serat}

Nugget tempe kontrol memiliki kadar serat tertinggi yaitu $216,5 \mathrm{mg} / 100 \mathrm{~g}$. Kandungan serat pangan pada tempe sebesar $1,4 \mathrm{~g} .{ }^{4}$ Serat tidak larut air pada tempe termasuk dalam golongan polisakarida (selulosa, hemiselulosa, pektin, lignin). Polisakarida tersebut tidak dapat dicerna oleh tubuh, tetapi merupakan serat pangan (dietary fiber) yang dapat menstimulasi enzim-enzim pencernaan. $^{10}$

Anjuran asupan serat berdasarkan American Dietetic Association adalah $14 \mathrm{~g} / 1000 \mathrm{kkal}$, atau $25 \mathrm{~g}$ untuk wanita dewasa dan $38 \mathrm{~g}$ untuk pria dewasa serta $19 \mathrm{~g}$ untuk anakanak. ${ }^{11}$ Kadar serat nugget tempe dengan substitusi ikan mujair 20\% menyumbangkan kecukupan serat berdasarkan rata-rata kebutuhan asupan serat per hari sebesar $0,57 \%$ untuk anak-anak; $0,43 \%$ untuk wanita dewasa; dan $0,28 \%$ untuk pria dewasa.

Selain untuk meningkatkan konsumsi serat, kandungan serat pangan pada nugget tempe substitusi ikan mujair berfungsi untuk menurunkan kadar kolesterol. Konsumsi serat yang tinggi berkaitan dengan pengeluaran asam empedu, sterol dan lemak lebih banyak bersama feses. Serat tersebut menurunkan kadar kolesterol dengan mencegah terjadinya penyerapan kembali asam empedu, kolesterol dan lemak. ${ }^{10}$

Hasil uji statistik menunjukkan tidak ada pengaruh substitusi ikan mujair terhadap kadar serat pada nugget yang disebabkan oleh analisis kandungan serat pangan hanya melalui metode ADF (Acid Detergent Fiber) yang dapat menganalisis kelompok selulosa dan lignin, sehingga tidak dapat mewakili kadar serat secara keseluruhan. ${ }^{12}$

\section{Kadar Lemak}

Kadar lemak terendah terdapat pada nugget tempe dengan substitusi ikan mujair 30\%, sedangkan kadar lemak tertinggi pada nugget tempe dengan substitusi ikan mujair $40 \%$ yaitu sebesar 19,08g/100g. Tingginya kadar lemak pada nugget dipengaruhi oleh proses penggorengan. Selama proses penggorengan, air pada nugget menguap sehingga sebagian minyak masuk ke dalam bagian nugget dan mengisi ruangan kosong yang sebelumnya diisi oleh air. ${ }^{13}$ Jumlah minyak yang diserap untuk mengempukkan bagian tengah nugget sesuai dengan jumlah air yang menguap. Semakin tebal lapisan tengah nugget, maka semakin banyak minyak yang akan diserap. ${ }^{14}$ 
Berdasarkan Badan Standarisasi Nasional (2002), kadar lemak pada nugget tempe substitusi ikan mujair tidak melebihi standar mutu nugget ayam yaitu maksimal $20 \%$ bb. ${ }^{9}$ Lemak pada tempe merupakan lemak tidak jenuh majemuk. Pada saat proses fermentasi tempe terjadi peningkatan derajat ketidakjenuhan lemak, asam palmitat dan linoleat sedikit mengalami penurunan, sedangkan asam lemak oleat dan linolenat mengalami peningkatan. Asam lemak tidak jenuh mempunyai efek terhadap penurunan kandungan kolesterol serum, sehingga dapat menetralkan efek negatif sterol dalam tubuh. ${ }^{15}$

Tidak adanya pengaruh substitusi ikan mujair terhadap kadar lemak pada nugget disebabkan oleh kandungan lemak ikan mujair hanya $1 \mathrm{~g}$, sehingga substitusi ikan mujair tidak memiliki pengaruh yang signifikan terhadap peningkatan kadar lemak pada nugget. Perbedaan kadar lemak pada nugget disebabkan oleh penyerapan minyak yang tidak dapat dikontrol selama proses penggorengan.

\section{Tingkat Penerimaan}

\section{a. Warna}

Hasil uji statistik tidak menunjukkan adanya perbedaan yang bermakna terhadap warna nugget. Hal tersebut dipengaruhi oleh karakteristik warna tempe dan daging ikan mujair yang putih sehingga warna nugget tempe substitusi ikan mujair memiliki warna yang dominan putih. Sedangkan permukaan nugget yang berwarna coklat dapat terjadi saat proses penggorengan yang mengakibatkan timbulnya reaksi maillard, yaitu reaksi pencoklatan non enzimatis karena adanya reaksi antara gula pereduksi dengan gugus amin bebas dari asam amino atau protein. Warna coklat merupakan hasil akhir dari reaksi aldehid yang aktif terpolimerisasi dengan gugus amino membentuk senyawa coklat yang disebut melanoidin. ${ }^{16}$

\section{b. Aroma}

Skor penilaian terendah yaitu 2.65 pada nugget tempe kontrol, hal tersebut dipengaruhi oleh aroma khas tempe. Tempe merupakan salah satu produk fermentasi kedelai yang memiliki senyawa penyebab off-flavor (penyimpangan cita rasa dan aroma pada produk olahan kedelai) yang berasal dari kedelai. Salah satu penyimpangan aromanya adalah bau langu. Bau langu ditimbulkan oleh kerja enzim lipoksigenase yang ada dalam biji kedelai. Enzim tersebut bereaksi dengan lemak dan menghasilkan suatu senyawa organik yaitu etil-fenil-keton. ${ }^{17}$

Pada nugget tempe dengan substitusi ikan mujair $10-50 \%$ aroma langu tidak mendominasi karena adanya penurunan aroma langu pada kedelai selama proses fermentasi dan pengukusan tempe, campuran daging ikan mujair juga menutupi aroma langu dari tempe, demikian halnya dengan aroma amis daging ikan mujair juga tidak terlalu mempengaruhi aroma nugget tempe substitusi ikan mujair.

\section{c. Tekstur}

Tekstur nugget tempe kontrol lebih padat namun tetap agak lembek. Nugget tempe dengan substitusi ikan mujair memiliki tekstur lebih lembek bila dibandingkan dengan nugget kontrol. Tekstur lembek dipengaruhi oleh struktur daging ikan mujahir yang lembut. Penambahan roti tawar sebagai bahan pengisi dan kuning telur sebagai pengemulsi yang diharapkan dapat meningkatkan tekstur nugget pada saat pengukusan ternyata masih kurang berfungsi mengisi sehingga tekstur nugget tetap lembek.

Kuning telur berfungsi sebagai pengemulsi suatu dispersi atau suspensi suatu cairan dalam cairan yang lain, dimana molekul-molekul kedua cairan tersebut tidak saling berbaur tetapi saling antagonistik. Air dan minyak merupakan cairan yang tidak saling berbaur, tetapi saling terpisah karena mempunyai berat jenis yang berbeda, sehingga emulsifier berfungsi untuk menjaga agar butir minyak tetap tersuspensi dalam air. ${ }^{10}$

\section{d. Rasa}

Rasa pada nugget tempe dengan substitusi ikan mujair $10 \%$ tidak disukai oleh panelis, sedangkan pada nugget tempe kontrol dan variasi substitusi ikan mujair $20-50 \%$ disukai oleh panelis. Rasa nugget dipengaruhi oleh rasa khas tempe (getir). Pada nugget tempe dengan substitusi ikan mujair 10\% tidak disukai panelis karena rasa getir mengakibatkan nugget kurang diminati. Sedangkan pada variasi persentasi substitusi ikan mujair 20-50\% disukai panelis karena rasa ikan mujair lebih dominan sehingga nugget lebih berasa gurih khas ikan.

Penambahan bumbu dilakukan untuk meningkatkan rasa nugget menjadi lebih sedap sehingga dapat menghasilkan rasa yang sama pada setiap perlakuan. Penggunaan minyak pada saat proses penggorengan juga berfungsi sebagai penambah rasa gurih pada bahan pangan. ${ }^{10}$ 
Berdasarkan hasil penelitian, dipilih nugget tempe dengan substitusi ikan mujair $20 \%$ karena merupakan produk yang disukai panelis, memiliki kadar protein 14,76g/100g; kadar serat $216 \mathrm{mg} / 100 \mathrm{~g}$; kadar lemak cukup rendah sebesar $16,74 \mathrm{~g} / 100 \mathrm{~g}$; serta asam amino esensial metionin $249 \mathrm{mg} / 100 \mathrm{~g}$ dan sistin $159 \mathrm{mg} / 100 \mathrm{~g}$.

\section{SIMPULAN}

1. Tidak ada pengaruh substitusi ikan mujair terhadap kadar protein nugget tempe. Nugget tempe dengan substitusi ikan mujair $10 \%$ memiliki kandungan protein tertinggi yaitu $15,05 \mathrm{~g} / 100 \mathrm{~g}$.

2. Tidak ada pengaruh substitusi ikan mujair terhadap kadar serat nugget tempe. Nugget tempe tanpa substitusi ikan mujair (kontrol) memiliki kandungan serat tertinggi yaitu $216,5 \mathrm{mg} / 100 \mathrm{~g}$.

3. Tidak ada pengaruh substitusi ikan mujair terhadap kadar lemak nugget tempe. Nugget tempe dengan substitusi ikan mujair 30\% memiliki kandungan lemak terendah yaitu $15,85 \mathrm{~g} / 100 \mathrm{~g}$.

4. Semua variasi substitusi ikan mujair pada nugget tempe dapat diterima dan disukai oleh panelis kecuali penilaian rasa pada nugget tempe dengan substitusi ikan mujair $10 \%$.

5. Kadar asam amino esensial meningkat pada setiap variasi substitusi ikan mujair. Nugget tempe dengan substitusi ikan mujair 20\% memiliki kadar asam amino metionin $249 \mathrm{mg} / 100 \mathrm{~g}$ dan sistin $159 \mathrm{mg} / 100 \mathrm{~g}$, namun sistin masih sebagai pembatas.

6. Konsumsi nugget tempe dengan substitusi ikan mujair $20 \%$ berdasarkan takaran saji lauk nabati $50 \mathrm{~g}$ dapat memenuhi $14,8 \%$ AKG protein bagi anak usia 6-12 tahun dan $12,3 \%$ AKG protein bagi dewasa usia $>15$ tahun. Kadar serat nugget tempe dengan substitusi ikan mujair 20\% menyumbangkan kecukupan serat berdasarkan rata-rata kebutuhan asupan serat per hari sebesar 0,57\% untuk anak-anak; $0,43 \%$ untuk wanita dewasa; dan $0,28 \%$ untuk pria dewasa.

\section{SARAN}

1. Berdasarkan hasil penelitian, nugget tempe yang direkomendasikan pada pembaca adalah nugget tempe dengan substitusi ikan mujair $20 \%$.
2. Bahan pengikat (maizena) dan emulsifier (soy protein isolate) dapat ditambahkan untuk memperbaiki tekstur nugget tempe.

3. Pada penelitian selanjutnya, dapat ditambahkan substitusi sumber bahan pangan nabati seperti brokoli untuk meningkatkan kadar asam amino esensial sistin pada nugget tempe.

4. Perlu dilakukan analisis zat gizi pada nugget tempe sebelum digoreng untuk mengetahui besar penyerapan minyak dan perubahan kandungan lemak serta zat gizi lain pada nugget tempe setelah digoreng.

\section{DAFTAR PUSTAKA}

1. Soendjojo Ramita D, Sritje Hikmat, Mien Sumartono. Menstimulasi Anak Usia 0-1 Tahun. Jakarta : Elexmedia Komputindo; 2000.

2. Departemen Kesehatan Republik Indonesia. Laporan Hasil Riset Kesehatan Dasar (RISKESDAS) Provinsi Jawa Tengah tahun 2007. Jakarta : Badan Penelitian dan Pengembangan Kesehatan; Desember 2008.

3. Anton Apriyantono. Problematika Ketahanan Pangan tahun 2007, Makalah Disampaikan dalam diskusi Peta Problematika Ketahanan Pangan yang diselenggarakan oleh Yayasan Solusi Bangsa pada 9 Juli 2008 di Jakarta.

4. Mien K. Mahmud, Hermana, Nils Aria Zulfianto, Apriyantono, dkk. Tabel Komposisi Pangan Indonesia (TKPI). Jakarta : Elex Media Komputindo; 2009. p.14;30.

5. Syamsir. Panduan Praktikum Pengolahan Pangan. Departemen Ilmu dan Teknologi Pangan. Bogor : Fateta IPB; 2006.

6. Koswara. Teknologi Pengolahan Kedelai Menjadi Makanan Bermutu. Jakarta : Pustaka Sinar Harapan; 1995.

7. Wisnu Cahyadi. Kedelai : Khasiat dan Teknologi. Jakarta : Bumi Aksara; 2007.p.4145.

8. Daftar Komposisi Zat Gizi Pangan Indonesia. Jakarta : Departemen Kesehatan; 1995.p.62-67.

9. Badan Standardisasi Nasional. 2002. Nugget Ayam. SNI 01-6683-2002. Jakarta : Badan Standardisasi Nasional

10. Winarno. Kimia Pangan dan Gizi. Jakarta : Gramedia Pustaka Utama; 2002.p.27;33-35;6970;95;115.

11. Position of the American Dietetic Association: Health Implications of Dietary Fiber. J Am Diet Assoc. 2008;108:1716.

12. Nuri Andarwulan, Feri Kusnandar, Dian Herawati. Analisis Pangan. Jakarta : Dian Rakyat; 2011.p.120-179;181-194.

13. Ketaren S. Pengantar Teknologi Minyak dan lemak Pangan. Jakarta : UI Press; 2005.p.61. 
14. Ratu Ayu DS. Pengaruh Suhu dan Lama Proses Menggoreng (deep frying) Terhadap Pembentukan Asam Lemak Trans. Makara Sains 2009; 13(1) : 23-28.

15. Made Astawan. Sehat Dengan Hidangan Kacang dan Biji-bijian. Jakarta : Penebar Swadaya; 2009.p.122-127.

16. Deddy Muchtadi. Teknik evaluasi nilai gizi protein. Bandung : Alfabeta; 2010.p.79.

17. Megia Esvandiari, Hayat Sholihin, Asep Suryatna. Studi Kinerja Adsorpsi Arang AktifBentonit Pada Aroma Susu Kedelai. Jurnal Sains dan Teknologi Kimia. 2010; 2(1) : 135149. 